Radomir Jovičić ${ }^{1}$, Olivera Erić Cekić ${ }^{7}$, Sanja Petronić ${ }^{1}$, Svetlana Štrbački ${ }^{2}$, Dejan Jovičić

\title{
DEFINITION OF WELDING PARAMETERS BY COOLING TIME IN TEMPERATURE RANGE 800-500 ${ }^{\circ} \mathrm{C}$
}

\section{DEFINISANJE PARAMETARA ZAVARIVANJA POMOĆU VREMENA HLADENJA U INTERVALU TEMPERATURA 800 - 500C}

\section{Originalni naučni rad / Original scientific paper}

Rad primljen / Paper received:

Septembar 2016.

Rad je u izvornom obliku objavljen u Zborniku sa savetovanja „ZAVARIVANJE 2016“ održanog na Srebrnom jezeru 14-17. Septembra 2016

Ključne reči: vreme hlađenja $t_{8 / 5}$, parametri zavarivanja, čelici, mikrostrukture, tvrdoće

Rezime: Vreme hlađenja $u$ temperaturnom intervalu $800-500^{\circ} \mathrm{C}\left(\mathrm{t}_{8 / 5}\right)$ ima veliki uticaj na strukture koje nastaju u zoni uticaja toplote zavarenih spojeva čelika. Podaci o optimalnim vremenima hlađenja $t_{8 / 5}$ za pojedine čelike se mogu naći u literaturi. $\mathrm{Na}$ veličinu vremena hlađenja $\mathrm{t}_{8 / 5}$, pri zavarivanju konkretnog spoja, pored debljine i fizičkih osobina zavarivanog čelika imaju uticaj i oblik spoja, postupak zavarivanja i parametri, kao što su temperatura predgrevanja, struja, napon i brzina zavarivanja. $U$ ovom radu je prikazan postupak za izbor parametara zavarivanja za jedan sučeoni spoj zavaren na mikrolegiranom čeliku $P$ 460 NL1. Prikazane su mikrostrukture u zoni uticaja toplote i rezultati merenja njihovih tvrdoća. Zaključeno je da parametri zavarivanja odabrani uz pomoć vremena hlađenja $t_{8 / 5}$ daju spoj sa zadovoljavajućim strukturama i tvrdoćama.

\section{UVOD}

Presudan uticaj na dobijene strukture u zoni uticaja toplote (ZUT) čelika imaju njegov hemijski sastav, struktura i vreme, odnosno, brzina hlađenja $\mathrm{u}$ temperaturnom intervalu najmanje stabilnosti austenita tj. u temperaturnom intervalu 800 $500^{\circ} \mathrm{C}$. Na brzinu hlađenja ZUT imaju uticaj fizičke osobine čelika (toplotna provodnost, specifična toplota), oblik i dimenzije spoja (debljina, sučeoni ili ugaoni spoj) i parametri zavarivanja (polazna temperatura i količina unete toplote). Promenom parametara zavarivanja može se, na određenom spoju, postići željeno vreme hlađenja u temperaturnom intervalu $800-500^{\circ} \mathrm{C}\left(\mathrm{t}_{8 / 5}\right) \mathrm{tj}$. može se postići vreme hlađenja koje u ZUT daje željenu

\author{
Adresa autora / Author's address: \\ 1 Inovacioni centar Mašinskog fakulteta Univerziteta $u$ \\ Beogradu, Srbija \\ 2 KonMat DOO, Beograd, Srbija \\ 3 MFGO DOO, Mladenovac, Srbija
}

Key words: cooling time $t_{8 / 5}$, welding parameters, steel, mikrostructure, hardness

Abstract: Cooling time in the temperature range $800-500^{\circ} \mathrm{C}$ has a great effect on the structures that arrise in the heat affected zone of welds steel. Data on optimal cooling time $t_{8 / 5}$ for the certain steels can be found in the literature. The period of the cooling time $t_{8 / 5}$, during the welding of the particular joints, in addition to the thickness and physical properties of welded steel, depends on shape of the weld, the welding process and welding parameters as well. In this work, the procedure for the selection of welding parameters for a butt joint welded to the microalloyed steel P $460 \mathrm{NL} 1$ is presented. The microstructure in the heat affected zone and the results of measurement of their hardness are showed and analysed. It is concluded that the welding parameters selected with the help of cooling time $t_{8 / 5}$ provide the satisfactory structure and hardness of welds.

strukturu. Kod različitih čelika, pri istom vremenu $t_{8 / 5}$ se dobijaju različite strukture, što je posledica razlika u hemijskim sastavima čelika. Vezu između struktura i vremena $t_{8 / 5}$ daju TTT dijagrami čelika. Zbog razlika u hemijskim sastavima i polaznim strukturama čelika potrebno je, pri izradi tehnologija zavarivanja, za svaku grupu čelika [1] odrediti dijapazon vremena $t_{8 / 5}$ koja daju željene strukture $u$ ZUT. Zatim je, za svaki konkretni zavareni spoj, propračunima potrebno odrediti količinu unete toplote $(Q)$, temperaturu predgrevanja $\left(T_{p}\right)$ i međuprolaznu temperaturu $\left(T_{m p}\right)$, koje obezbeđuju da vreme $t_{8 / 5}$ bude $u$ okviru željenog, odnosno zadatog vremena za zavarivani čelik. Kada postoje 
ograničenja u veličini jednog od parametara $(Q$ ili $T_{p}$ ) proračunima se može utvrditi koliki treba da bude drugi parametar da bi vreme $t_{8 / 5}$ ostalo $u$ zadatim okvirima. Na taj način se uvek na osnovu poznatog vremena $t_{8 / 5}$ mogu izračunati optimalni parametri zavarivanja.

Niskougljenični sitnozrni i mikrolegirani čelici, se danas proizvode sa strogo definisanim hemijskim sastavima i u uslovima precizno vođenih režima termomehaničke obrade pri valjanju. $\mathrm{Na}$ taj način dobijaju se strukture koje imaju visoku čvrstoću i plastičnost i dobru žilavost. Ovako dobijene strukture su osetljive na naknadno zagrevanje. Zbog toga se, pri zavarivanju lako transformišu, pri čemu se karakteristike čvrstoće i žilavosti smanjuju. Zbog toga je važno da se pri zavarivanju ovi čelici kontrolisano zagrevaju i hlade. Naročito je važno vreme $t_{8 / 5}$. Sklonost mikrostruktura čelika ka promenama pri zavarivanju je utoliko veća ukoliko je viši napon tečenja čelika. Zato sa porastom napona tečenja, kod ovih čelika, raste važnost preciznog određivanja i kontrolisanja vremena $t_{8 / 5}$.

\section{PRORAČUN VREMENA HLAĐENJA $t_{8 / 5}$}

$U$ daljem tekstu su proračunata vremena $t_{8 / 5}$ za različite $T_{p}$ i $Q$, za sučeoni spoj na čeliku $P 460$ $\mathrm{NL} 1$, debljine $14 \mathrm{~mm}$. Hemijski sastav OM, koji je upotrebljen u eksperimentalnom delu ovog rada, određen je spektralnom analizom i dat je u tabeli 1 .

\begin{tabular}{|c|c|c|c|c|c|c|c|c|}
\hline Element & $\mathrm{C}$ & $\mathrm{Si}$ & $\mathrm{Mn}$ & $\mathrm{P}$ & $\mathrm{S}$ & $\mathrm{Al}$ & $\mathrm{Cr}$ & $\mathrm{Ni}$ \\
\hline$\%$ & 0,153 & 0,380 & 1,40 & 0,015 & 0,0021 & 0,031 & 0,037 & 0,630 \\
\hline Element & $\mathrm{Mo}$ & $\mathrm{Cu}$ & $\mathrm{V}$ & $\mathrm{Nb}$ & $\mathrm{Ti}$ & $\mathrm{B}$ & $\mathrm{N}$ & - \\
\hline$\%$ & 0,004 & 0,061 & 0,099 & 0,038 & 0,004 & 0,0003 & 0,0052 & \\
\hline
\end{tabular}

Tabela 1. Hemijski sastav osnovnog materijala, P 460 NL1

\subsection{Proračun vremena $t_{8 / 5}$ u ZUT korenog prolaza, zavarenog bez predgrevanja}

Postupak za određivanje vremena $t_{8 / 5}$ je dat u literaturi [2]. Prvi korak u proračunu je određivanje prelazne debljine OM, pri kojoj se odvođenje toplote menja iz dvodimenzionalnog $u$ trodimenzionalno. Ukoliko je debljina OM, u konkretnom slučaju, manja od prelazne debljine odvođenje toplote je dvodimenzionalno, a ukoliko je ta debljina veća od prelazne debljine, odvođenje toplote je trodimenzionalno. Iz literature [2] se, za uslove zavarivanja ovog korenog prolaza $(\mathrm{d}=14$ $\mathrm{mm} ; \mathrm{T}_{\mathrm{p}}=20^{\circ} \mathrm{C} ; \mathrm{Q}=1,25 \mathrm{KJ} / \mathrm{mm}$, tabela 2.), vidi da je prelazna debljina jednaka $18 \mathrm{~mm}$. S obzirom da je debljina OM manja od prelazne debljine, u konkretnom slučaju se radi o dvodimenzionalnom odvođenju toplote.

Količina unete toplote $Q$ je izračunata iz jednačine: $Q=\eta \cdot I \cdot U /\left(v_{z} \cdot 1000\right) \mathrm{KJ} / \mathrm{mm}$, gde su: $\eta$ - koeficijent termičkog iskorišćenja za MIG postupak 0,8 ; I - jačina stuje zavarivanja $A$; U napon zavarivanja $\mathrm{V} ; \mathrm{v}_{\mathrm{z}}$ - brzina zavarivanja $\mathrm{mm} / \mathrm{sec}$. Parametri zavarivanja ( $\left(\begin{array}{lll}U & U, & \left.V_{z}\right)\end{array}\right.$ preporučeni za zavarivanje korenog prolaza na sučeonom spoju, MIG postupkom, punom žicom prečnika $1,2 \mathrm{~mm}$ u PA položaju su dati u tabeli 2 . i literaturi [3]. Jednačina za određivanje vremena $t_{8 / 5}$ za nelegirane i niskolegirane čelike, gde spada i mikolegirani čelik $P \quad 460 \quad \mathrm{NL} 1$, pri dvodimenzionalnom odvođenju toplote je data $u$ literaturi [2] i glasi:

$$
t_{8 / 5}=\left(4300-4,3 T_{p}\right) \cdot 10^{5} \cdot Q^{2} / d^{2} \cdot[1 /(500-
$$
$\left.\left.T_{p}\right)^{2}-1 /\left(800-T_{p}\right)^{2}\right] \cdot F_{2}$ sec

gde su: $T_{p}$ - temperatura predgrevanja ${ }^{\circ} \mathrm{C} ; \mathrm{Q}-$ količina toplote unete pri zavarivanju $\mathrm{KJ} / \mathrm{mm}$; $\mathrm{d}-$ debljina OM mm; $F_{2}$ - faktor oblika spoja $(0,9$ za višeprolazni sučeoni spoj

\begin{tabular}{|c|c|c|c|c|c|c|c|c||}
\hline $\begin{array}{c}\text { Red. } \\
\text { br. }\end{array}$ & & $\begin{array}{c}\mathrm{T}_{\mathrm{p}} \\
{ }^{\circ} \mathrm{C}\end{array}$ & $\begin{array}{c}\mathrm{I} \\
\mathrm{A}\end{array}$ & $\begin{array}{c}\mathrm{U} \\
\mathrm{V}\end{array}$ & $\begin{array}{c}\mathrm{v}_{\mathrm{z}} \\
\mathrm{cm} / \mathrm{min}\end{array}$ & $\begin{array}{c}\mathrm{v}_{\mathrm{z}} \\
\mathrm{mm} / \mathrm{sec}\end{array}$ & $\begin{array}{c}\mathrm{Q} \\
\mathrm{KJ} / \mathrm{mm}\end{array}$ & $\begin{array}{c}\mathrm{t}_{8 / 5} \\
\mathrm{sec}\end{array}$ \\
\hline \hline 1 & Bez predgrevanja & 20 & 130 & 16,0 & 8,0 & 1,33 & 1,25 & 8,2 \\
\hline 2 & Predgrevanje prema proračunu & 40 & 130 & 16,0 & 8,0 & 1,33 & 1,25 & 8,9 \\
\hline 3 & Optimalne vrednosti & 150 & 130 & 16,0 & 8,0 & 1,33 & 1,25 & 15,2 \\
\hline 4 & Minimalne vrednosti & 150 & 120 & 15,8 & 8,5 & 1,42 & 1,07 & 11,4 \\
\hline
\end{tabular}

Tabela 2. Parametri zavarivanja i vremena hlađenja $t_{8 / 5}$ za koreni prolaz 
Preporučena vremena $t_{8 / 5}$ za mikrolegirane čelike, se kreću u intervalima 10 - $25 \mathrm{sec}$ [2], 5 - $20 \mathrm{sec}$ [4] i $15 \mathrm{sec}$ [5]. Za potrebe ovog rada, kao optimalna, usvojena su vremena $t_{8 / 5}$ od $10-20 \mathrm{sec}$. Iz tabele 2. se vidi da vreme $t_{8 / 5}$ za zavarivanje korenog prolaza u navedenim uslovima i iznosi $8,2 \mathrm{sec}$. što je manje od preporučenih vrednosti. Da bi se vreme hlađenja ZUT korenog prolaza produžilo potrebno je predgrevanje OM.

\subsection{Proračun temperature predgrevanja $i$} vremena $t_{8 / 5}$ u ZUT korenog prolaza

Postupak za izračunavanje $T_{p}$ je dat $u$ literaturi [2]. Visina $T_{p}$ za napred navedene uslove zavarivanja korenog prolaza je data u tabeli 3 .

\begin{tabular}{|c|c|c|c|c||}
\hline & & Jednačine & Parametri & Temperatura ${ }^{\circ} \mathrm{C}$ \\
\hline \hline 1 & $\mathrm{~T}_{\mathrm{pCET}}$ & $\mathrm{T}_{\mathrm{pCET}}=750 \cdot \mathrm{CET}-150$ & $\mathrm{CET}=0,314$ & $+85,5$ \\
\hline 2 & $\mathrm{~T}_{\mathrm{pd}}$ & $\mathrm{T}_{\mathrm{pd}}=160 \cdot \tanh (\mathrm{d} / 35)-110$ & $\mathrm{~d}=14 \mathrm{~mm}$ & $-49,2$ \\
\hline 3 & $\mathrm{~T}_{\mathrm{pHD}}$ & $\mathrm{T}_{\mathrm{pHD}}=62 \cdot \mathrm{HD}^{0,35}-100$ & $\mathrm{HD}=5 \mathrm{ml} / 100 \mathrm{gr}$ & $+3,7$ \\
\hline 4 & $\mathrm{~T}_{\mathrm{pQ}}$ & $\mathrm{T}_{\mathrm{pQ}}=(53 \cdot \mathrm{CET}-32) \mathrm{Q}-53 \cdot \mathrm{CET}+32$ & $\mathrm{Q}=1,25 \mathrm{KJ} / \mathrm{mm}$ & 0 \\
\hline 5 & $\mathrm{~T}_{\mathrm{p}}$ & $\mathrm{T}_{\mathrm{p}}=\mathrm{T}_{\mathrm{pCET}}+\mathrm{T}_{\mathrm{pd}}+\mathrm{T}_{\mathrm{pHD}}+\mathrm{T}_{\mathrm{pQ}}$ & - & 40 \\
\hline
\end{tabular}

Tabela 3. Propračun temperature predgrevanja za koreni prolaz, [2]

Ako izračunatu $T_{p}$ od $40^{\circ} \mathrm{C}$, tabela 3 . uvrstimo $u$ jednačinu (1) uz zadržavanje istog unosa toplote $Q$, dobija se da je vreme $t_{8 / 5}$ jednako $8,9 \mathrm{sec}$, što je $\mathrm{i}$ dalje manje od preporučenih vrednosti za ovaj čelik.

Navedene vrednosti pokazuju da je $T_{p}$ potrebno značajno povećati. Proračun prelazne debljine OM pokazuje da je, pri temperaturi predgrevanja od $150^{\circ} \mathrm{C}$ i nepromenjenoj veličini $Q$, prenos toplote i dalje dvodimenzionalan i da se zato za proračun vremena $t_{8 / 5} i$ dalje može koristiti jednačina (1). Proračun po ovoj jednačini pokazuje da se pri predgrevanju na $150^{\circ} \mathrm{C}$ vreme $t_{8 / 5}$ nalazi oko sredine oblasti preporučenih vrednosti, tabela 2 . Manje oscilacije jačine struje i brzine zavarivanja menjaju količinu unete toplote što onda bitno menja vreme $t_{8 / 5}$. Zbog toga je pogodno da se izabere $T_{p}$ koja daje vreme $t_{8 / 5}$ oko sredine preporučene oblasti.

\subsection{Proračun temperature predgrevanja $i$ vremena $t_{8 / 5} u$ ZUT prolaza popune}

Prolazi popune se po pravilu zavaruju strujama većih jačina i sa većim brzinama zavarivanja, što može da povećava količinu unete toplote. Preporučeni parametri zavarivanja [3] kao i količina unete energije za prolaze popune su dati u tabeli 4 .

$\mathrm{U}$ praksi se često dešava da prostor, odnosno, "žlebovi" za polaganje pojedinih prolaza u popuni višeprolaznih šavova imaju različite dimenzije. To je posledica lošeg rasporeda polaganja pojedinih prolaza i uklanjanja grešaka brušenjem. Različite dimenzije ovih "žlebova" uslovljavaju različite brzine zavarivanja u pojedinim prolazima, što onda menja količinu unete toplote i vreme $t_{8 / 5}$. Na osnovu iskustva iz prakse usvojeno je da se, u uslovima zavarivanja opisanih spojeva, brzina zavarivanja može menjati u granicama 20 do $27 \mathrm{~cm} / \mathrm{min}$, što onda menja količinu unete toplote u granicama 1,23 do $1,67 \mathrm{KJ} / \mathrm{mm}$, tabela 4 . Proračuni po jednačini (1) (odvođenje toplote je dvodimenzionalno) pokazuju da jedino međuprolazna temperatura od $90^{\circ} \mathrm{C}$ obezbeđuje da se pri ovim količinama unete toplote vreme $t_{8 / 5}$ održava u granicama 10 do $20 \mathrm{sec}$.

\begin{tabular}{|c|c|c|c|c|c|c|c|c||}
\hline \hline & & $\begin{array}{c}\mathrm{T}_{\mathrm{p}} \\
{ }^{\circ} \mathrm{C}\end{array}$ & $\begin{array}{c}\mathrm{I} \\
\mathrm{A}\end{array}$ & $\begin{array}{c}\mathrm{U} \\
\mathrm{V}\end{array}$ & $\begin{array}{c}\mathrm{V}_{\mathrm{z}} \\
\mathrm{cm} / \mathrm{min}\end{array}$ & $\begin{array}{c}\mathrm{V}_{\mathrm{z}} \\
\mathrm{mm} / \mathrm{sec}\end{array}$ & $\begin{array}{c}\mathrm{Q} \\
\mathrm{KJ} / \mathrm{mm}\end{array}$ & $\begin{array}{c}\mathrm{t}_{8 / 5} \\
\mathrm{sec}\end{array}$ \\
\hline \hline 1 & Preporučeni parametri & 80 & 230 & 30 & 25 & 4,2 & 1,31 & 12,0 \\
\hline 2 & Zavarivanje maks. brzinom & 90 & 230 & 30 & 27 & 4,5 & 1,23 & 10,6 \\
\hline 3 & Zavarivanje min. brzinom & 90 & 230 & 30 & 20 & 3,3 & 1,67 & 18,2 \\
\hline 4 & Zavarivanje smanjenom strujom & 90 & 225 & 29,5 & 25 & 4,2 & 1,26 & 11,3 \\
\hline 5 & Zavarivanje povećanom strujom & 90 & 240 & 30,5 & 25 & 4,2 & 1,39 & 14,0 \\
\hline 6 & Optimalne vrednosti & 90 & 230 & 30 & 25 & 4,2 & 1,31 & 12,7 \\
\hline
\end{tabular}

Tabela 4. Parametri zavarivanja $i$ vremena hlađenja $t_{8 / 5}$ za prolaze popune 
Zbog promene dužine slobodnog kraja žice, tokom zavarivanja, dolazi do manjih promena jačine struje i napona zavarivanja. Odstupanja ovih veličina, data u tabeli 4. su usvojena na osnovu iskustva iz prakse. Iz tabele se vidi da, pri $\mathrm{T}_{\mathrm{p}}$ od $90^{\circ} \mathrm{C}$, odstupanja struje i napona ne dovode do nedozvoljenih odstupanja vremena $t_{8 / 5}$.

\section{EKSPERIMENT}

$\mathrm{Za}$ ispitivanje uticaja parametara zavarivanja na vreme $t_{8 / 5}$ i na osobine čelika $P 460$ NL 1 u ZUT, MIG postupkom, su zavarena dva sučeona spoja na pločama dimenzija 200 x 500 x $14 \mathrm{~mm}$. Korišćena su dodatni materijali: puna žica VAC 65 (AWS ER 70S-6) prečnika 1,2 mm za spoj 1 i punjena žica Filtub 12 M (AWS E71T-1MH4) prečnika 1,2 mm za spoj 2., proizvođača Elektrode Jesenice [6]. Kao zaštitni gas u oba slučaja korišćena je mešavina $\mathrm{Ar}+5,9 \% \mathrm{CO}_{2}+1,1 \% \mathrm{O}_{2}$. Zavarivanje je izvedeno na uređaju Kemppi
FastMig 350 Pulse, sa dodavačem FastMig MXF 65. Tokom zavarivanja kontinualno su snimani struja i napon pomoću uređaja Kemppi ARC I. Uređaj omogućava da se struja i napon očitaju u svakom trenutku tokom zavarivanja i da se odrede njihove srednje vrednosti tokom zavarivanja svakog prolaza. Ove vrednosti su korišćene za izračunavanje stvarne količine unete toplote i date su u tabeli 5.

\section{REZULTATI ISPITIVANJA}

\subsection{Parametri zavarivanja i vremena hlađenja $\mathbf{t}_{8 / 5}$}

$U$ tabeli 5. su date temperature predgrevanja $T_{p}$, međuprolazne temperature $\mathrm{T}_{\mathrm{mp}}$, struja, napon i brzina zavarivanja svakog prolaza, na oba spoja, kao i njima odgovarajuće količine toplote $Q$, prelazne debljine $d_{t} i$ vremena $t_{8 / 5}$.

\begin{tabular}{|c|c|c|c|c|c|c|c|c||}
\hline \multicolumn{2}{|c|}{ Spoj/Prolaz } & $\mathrm{T}_{\mathrm{p}} / \mathrm{T}_{\mathrm{mp}}\left({ }^{\circ} \mathrm{C}\right)$ & $\mathrm{I}(\mathrm{A})$ & $\mathrm{U}(\mathrm{V})$ & $\mathrm{V}_{\mathrm{z}}(\mathrm{cm} / \mathrm{min})$ & $\mathrm{Q}(\mathrm{KJ} / \mathrm{mm})$ & $\mathrm{d}_{\mathrm{t}}(\mathrm{mm})$ & $\mathrm{t}_{8 / 5}(\mathrm{sec})$ \\
\hline \hline \multirow{4}{*}{ Spoj } & 1 & 150 & 122 & 16,2 & 7,9 & 1,20 & 18 & 11,0 \\
\cline { 2 - 10 } & 2 & 97 & 210 & 20,3 & 15,4 & 1,33 & 18 & 13,0 \\
\cline { 2 - 10 } & 3 & 92 & 242 & 28,9 & 22,4 & 1,51 & 20 & 16,9 \\
\cline { 2 - 10 } & 4 & 105 & 218 & 26,1 & 33,7 & 0,81 & 14 & 4,5 \\
\cline { 2 - 10 } & 5 & 90 & 222 & 26,3 & 20,7 & 1,35 & 17 & 12,6 \\
\hline \hline \multirow{4}{*}{$\begin{array}{c}\text { Spoj } \\
2 .\end{array}$} & 1 & 155 & 122 & 15,8 & 8,5 & 1,09 & 17 & 11,8 \\
\cline { 2 - 10 } & 2 & 105 & 217 & 26,7 & 19,2 & 1,45 & 20 & 15,0 \\
\cline { 2 - 10 } & 4 & 96 & 232 & 27,7 & 21,4 & 1,44 & 19 & 15,8 \\
\cline { 2 - 10 } & 5 & 90 & 239 & 27,9 & 22,6 & 1,41 & 18 & 14,0 \\
\hline \hline
\end{tabular}

Tabela 5. Parametri zavarivanja i vremena hlađenja $t_{8 / 5}$ spojeva 1. $i 2$.

\subsection{Makrostrukture i tvrdoće}

Iz zavarenih spojeva su isečeni uzorci za ispitivanja makro i mikrostruktura i za merenja tvrdoća. Nakon poliranja uzorci su nagriženi (4\% rastvor nitala) čime su otkrivene granice OM, ZUT i MŠ, što je

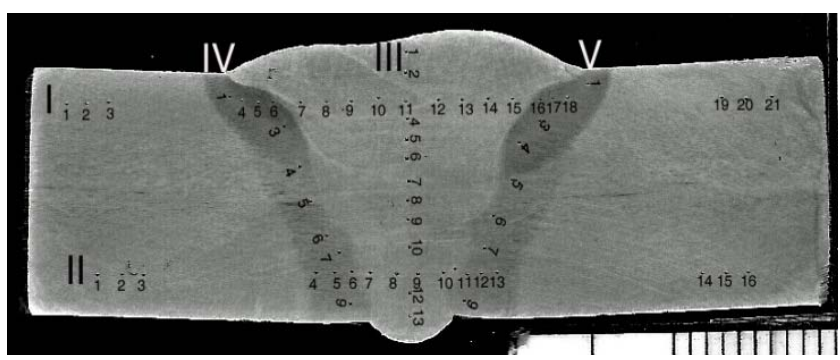

a) omogućilo da se tačno odredi pozicija svakog pojedinačnog otiska. Vikersovom metodom su, sa opterećenjem od $10 \mathrm{dN}$ (HV 10), izmerene tvrdoće. $\mathrm{Na}$ slici 1. su date makrostrukture i raspored mesta merenja tvrdoća na oba spoja, a u tabelama 6. i 7. su dati rezultati merenja ovih tvrdoća.

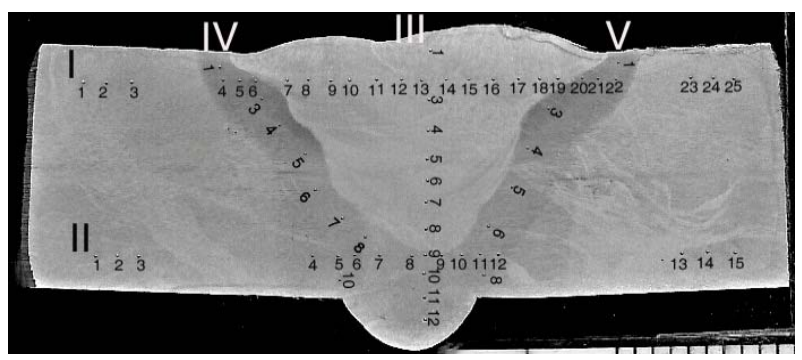

b)

Slika 1. Makrostrukture i raspored mesta merenja tvrdoća: a) spoj 1.; b) spoj 2. 


\begin{tabular}{|c|c|c|c|c|c|c|c|}
\hline $\begin{array}{c}\text { Linija br. } 1 \\
\text { merno mesto }\end{array}$ & Tvrdoća & $\begin{array}{c}\text { Linija br. } 2 \\
\text { merno mesto }\end{array}$ & Tvrdoća & $\begin{array}{c}\text { Linija br. } 4 \\
\text { merno mesto }\end{array}$ & Tvrdoća & $\begin{array}{l}\text { Linija br. } 5 \\
\text { merno mesto }\end{array}$ & Tvrdoća \\
\hline $1-3 / O M$ & 191 & 1-3/OM & $187-188$ & $1 / \mathrm{ZUT}$ & 266 & $1 / Z U T$ & 258 \\
\hline $4 / Z U T$ & 283 & 4/ZUT & 201 & 2/ZUT & 283 & $2 / Z U T$ & 283 \\
\hline $5 / Z U T$ & 304 & $5 / Z U T$ & 206 & $3 / \mathrm{ZUT}$ & 297 & $3 / \mathrm{ZUT}$ & 272 \\
\hline $6 / Z U T$ & 304 & $6 / Z U T$ & 224 & 4/ZUT & 232 & $4 / Z U T$ & 279 \\
\hline 7-15/MŠ & $206-225$ & 7-13/MŠ & $201-202$ & $5 / Z U T$ & 230 & $5 / Z U T$ & 236 \\
\hline 16/ZUT & 289 & 11/ZUT & 219 & 6/ZUT & 233 & 6/ZUT & 243 \\
\hline 17/ZUT & 283 & 12/ZUT & 210 & 7/ZUT & 230 & 7/ZUT & 228 \\
\hline 18/ZUT & 276 & 13/ZUT & 199 & 8/ZUT & 224 & 8/ZUT & 219 \\
\hline 19-21/OM & $185-188$ & 14-16/OM & $183-186$ & 9/ZUT & 230 & 9/ZUT & 228 \\
\hline
\end{tabular}

Tabela 6. Tvrdoće izmerene na spoju 1. (HV10)

\begin{tabular}{|c|c|c|c|c|c|c|c|}
\hline $\begin{array}{c}\text { Linija br. } 1 \\
\text { merno mesto }\end{array}$ & Tvrdoća & $\begin{array}{c}\text { Linija br. } 2 \\
\text { merno mesto }\end{array}$ & Tvrdoća & $\begin{array}{l}\text { Linija br. } 4 \\
\text { merno mesto }\end{array}$ & Tvrdoća & $\begin{array}{l}\text { Linija br. } 5 \\
\text { merno mesto }\end{array}$ & Tvrdoća \\
\hline $1-3 / \mathrm{OM}$ & $176-179$ & $1-4 / \mathrm{OM}$ & $187-191$ & $1 /$ ZUT & 242 & $1 / \mathrm{ZUT}$ & 258 \\
\hline 4/ZUT & 221 & $5 / Z U T$ & 232 & $2 / Z U T$ & 271 & 2/ZUT & 274 \\
\hline $5 / Z U T$ & 266 & 6/ZUT & 254 & 3/ZUT & 274 & 3/ZUT & 279 \\
\hline 6/ZUT & 274 & - & - & 4/ZUT & 245 & 4/ZUT & 242 \\
\hline 7-19/MŠ & $201-216$ & 7-9/MŠ & $205-206$ & $5 / \mathrm{ZUT}$ & 254 & $5 / \mathrm{ZUT}$ & 242 \\
\hline 20/ZUT & 274 & 10/ZUT & 254 & 6/ZUT & 225 & 6/ZUT & 238 \\
\hline 21/ZUT & 274 & 11/ZUT & 235 & 7/ZUT & 230 & 7/ZUT & 235 \\
\hline 22/ZUT & 236 & 12/ZUT & 235 & $8 / Z U T$ & 230 & 8/ZUT & 240 \\
\hline \multirow[t]{2}{*}{$23-25 / \mathrm{OM}$} & $185-188$ & 13-15/OM & $183-188$ & 9/ZUT & 224 & & \\
\hline & & & & 10/ZUT & 247 & & \\
\hline
\end{tabular}

Tabela 7. Tvrdoće izmerene na spoju 2. (HV10)

\subsection{Mikrostrukture}

$\mathrm{Na}$ slici 2. su prikazane karakteristične mikrostrukture OM i ZUT u zoni korena i u zoni lica šava. Na slici 2.a) prikazana je fertino-perlitna mikrostruktura OM. Tamne linije pretstavljaju strukturne segregacije koje su uočene oko sredine debljine ploče. Na slici 2.b) prikazana je feritnobeinitno-perlitna mikrostruktura u grubozrnom delu ZUT u zoni korena šava. Slike 2. c) i d) prikazuju mikrostrukture u ZUT završnih prolaza tj. zoni lica šava. Na slici 2.c) je prikazana beinitno-martenzitna mikrostruktura u grubozrnom delu ZUT završnih prolaza. Mikrostrukturnim ispitivanjem je konstatovano da se u ZUT ovih prolaza na oba spoja javlja oko $20 \%$ martenzita. Slika 2.d) prikazuje beinitno-martenzitno-perlitnu mikrostrukturu ZUT na liniji stapanja završnog prolaza. 


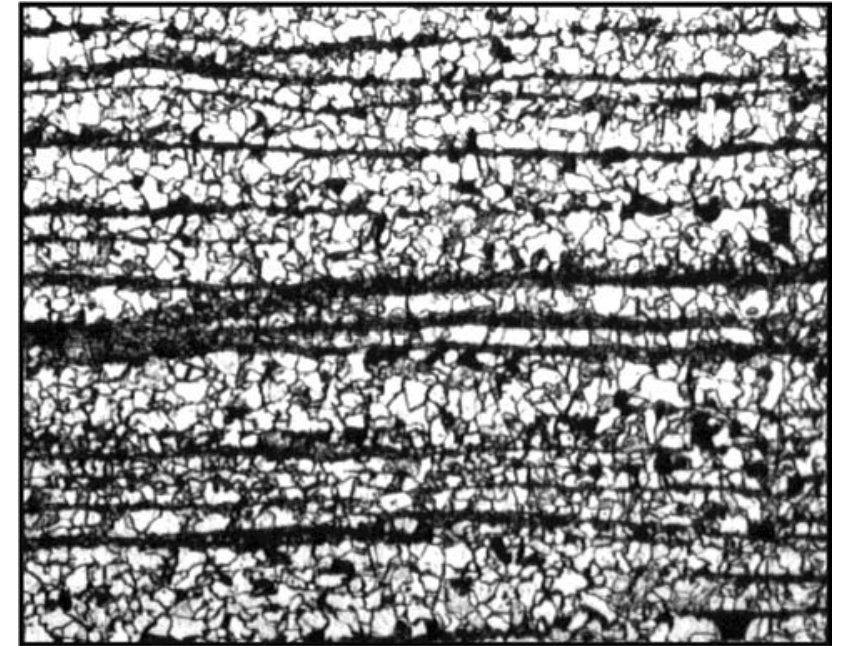

a)

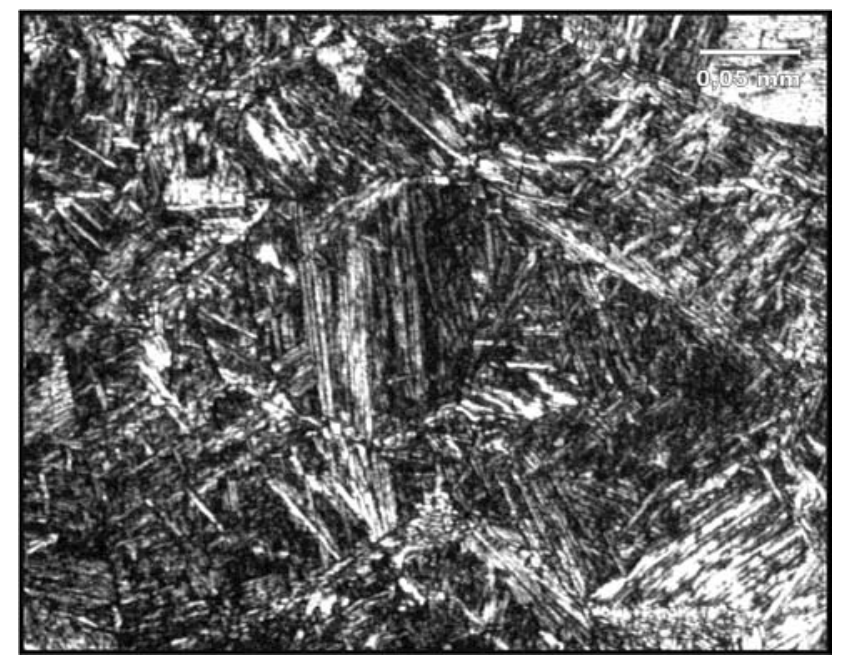

c)
$200 x$

$200 x$

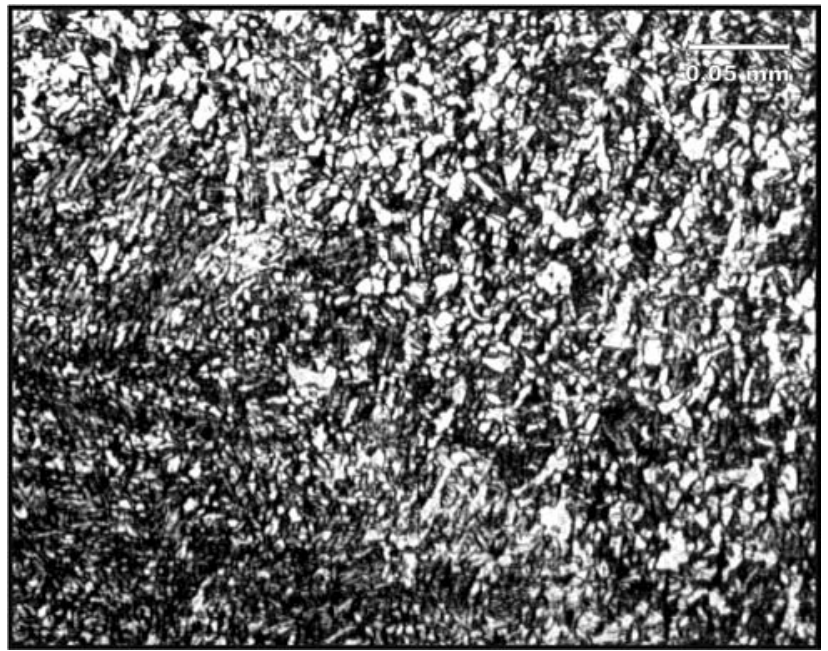

b)

$200 x$

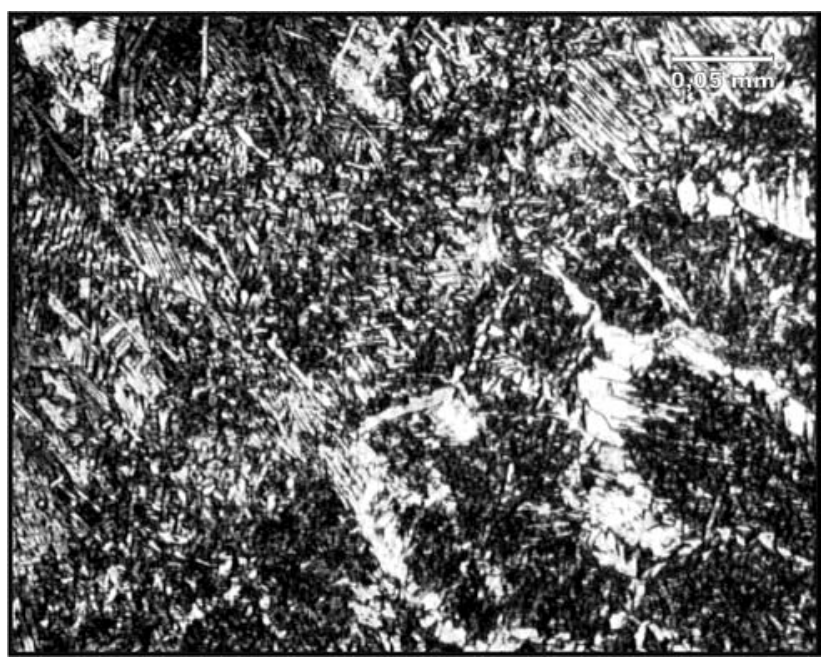

d)

$200 x$

Slika 2. a) osnovni metal, b) ZUT u korenom delu šava, c) ZUT u zoni lica šava, d) ZUT i linija stapanja u zoni lica šava

\section{ANALIZA REZULTATA}

Odnosi između vremena $t_{8 / 5}$ i dobijenih struktura i tvrdoća u ZUT se mogu pratiti na TTT dijagramu čelika, slika 3 . Dijagram pokazuje da se sa skraćenjem vremena $t_{8 / 5}$ u ZUT smanjuje udeo ferita i da raste udeo perlita, što je praćeno povećanjem tvrdoće. Pri određenom vremenu hlađenja u strukturi se pojavljuje beinit, čiji udeo raste kako se vreme $t_{8 / 5}$ skraćuje. Porast udela beinita je praćen smanjenjem udela feritnoperlitnog mikrokonstituenta, što ima za posledicu dalje povećanje tvrdoća. Od određenog vremena hlađenja u strukturi se pojavljuje i martenzit čiji udeo raste sa skraćenjem vremena $t_{8 / 5}$, što je, takođe, praćeno povećanjem tvrdoće. $U$ literaturi $[7,8]$ se kao maksimalna vrednost tvrdoće koja se sme dozvoliti u ZUT niskougljeničnih čelika navodi tvrdoća od $350 \mathrm{HV}$. Preko ove tvrdoće strukture postaju sklone nastanku hladnih prslina.

Produženje vremena $t_{8 / 5}$ dovodi do smanjenja tvrdoća u ZUT. Razlozi za to su, pored smanjenja udela perlita, povećanje veličine zrna, naročito $u$ krupnozrnom delu ZUT i proširenje ovog dela ZUT. Do pada tvrdoće dolazi i u onim delovima ZUT gde se preklapaju ZUT pojedinih prolaza tj. u onim delovima ZUT koji su pretrpeli dvostruki termički ciklus. 


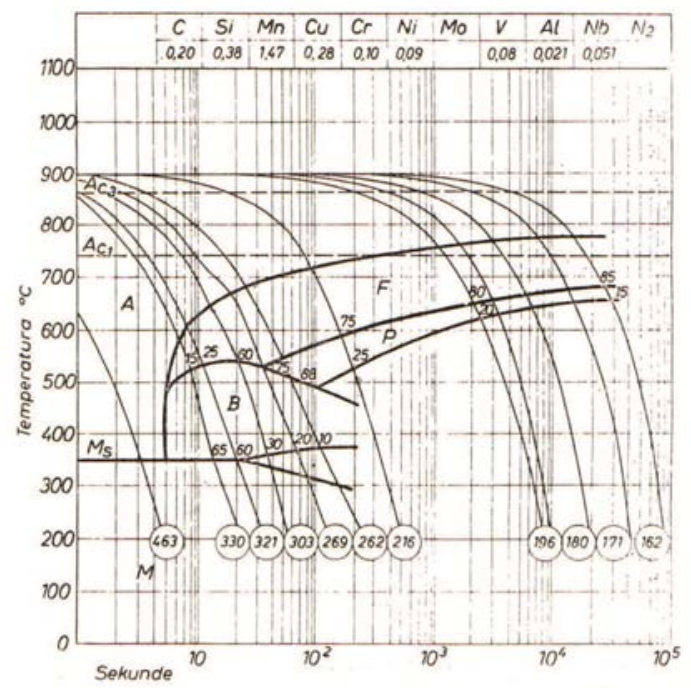

Slika 3. TTT dijagram čelika P 460 NL1

Može se zaključiti da tvrdoće u ZUT niskougljeničnih čelika ne treba da budu manje od tvrdoća OM, jer to onda znači da će ZUT imati nižu čvrstoću i žilavost u odnosu na OM. Takođe, tvrdoće u ZUT ne treba da budu veće od $350 \mathrm{HV}$. Slika 3. pokazuje da tvrdoćama koje su nešto niže, a bliske ovoj vrednosti (kriva $330 \mathrm{HV}$ ) odgovara beinitna mikrostrukturi sa udelom ferita 15 do $20 \%$ i sa udelom martenzita do oko $20 \%$. S obzirom da nivo tvrdoća ovakvih struktura zavisi od hemijskog sastava i polazne mikrostrukture OM nije moguće preciznije definisati optimalne udele strukturnih komponenti u ZUT. Za niskougljenične čelike se načelno može reći da tvrdoće u ZUT ne treba da budu van granica $200-300 \mathrm{HV}$.

U tabelama 2. i 4. su dati optimalni parametri za zavarivanje korenog prolaza i prolaza popune, a u tabeli 5. su dati parametri po kojima su pojedini prolazi u oba spoja zavareni. Iz tabela se vidi da su pri zavarivanju oba uzorka $\mathrm{T}_{\mathrm{p}}$ i $\mathrm{T}_{\mathrm{mp}}$ bile $\mathrm{u}$ propisanim okvirima. Pri zavarivanju korenog prolaza spoja 1. unos toplote bio nešto manji od optimalnog, zbog čega je i vreme $t_{8 / 5}$ bilo nešto kraće (11,0 sec.) od optimalnog. Unos toplote u pojedinim prolazima popune, ovog spoja, je bio neujenačen, zbog čega je $i$ vreme $t_{8 / 5} u$ pojedinim prolazima bilo neujednačeno i kretalo se od 4,5 - 16,9 sec. Raspodela tvrdoća po debljini spoja 1., tabela 6., pokazuje da se u korenom delu spoja tvrdoće kreću od 210 - $230 \mathrm{HV}$, a da se u zoni lica spoja tvrdoće povećavaju na 260 - $300 \mathrm{HV}$. Pri zavarivanju korenog prolaza spoja 2. unos toplote je, takođe, bio nešto manji od optimalnog, zbog čega je i vreme $t_{8 / 5}$ nešto bilo kraće $(11,8$ sec.) od optimalnog. Unos toplote u pojedinim prolazima popune je, u ovom spoju, bio ujednačen. Zbog toga je i vreme hlađenja $t_{8 / 5} \mathrm{u}$ pojedinim prolazima bilo ujednačenije i kretalo se od 14,0 - 18,2 sec. Raspodela tvrdoća po debljini spoja 2., tabela 7., pokazuje da se u korenom delu spoja tvrdoće kreću od 230 - $250 \mathrm{HV}$, a da se u zoni lica spoja tvrdoće povećavaju na $270-280 \mathrm{HV}$.

Iz tabele 5. se vidi da su na oba spoja, u svim prolazima, postignuta vremena $t_{8 / 5}$ koja su u okviru propisanog raspona (10 - $20 \mathrm{sec}$.). Samo je u slučaju prolaza br. 4 na spoju 1 . vreme $t_{8 / 5}$ znatno kraće od propisanog (4,5 sec). Iz tabele se, takođe, vidi da je spoj 1. zavaren sa, ukupno gledano manjim unosom toplote od spoja 2. Najveća tvrdoća (304 HV) je izmerena u ZUT prolaza 4. spoja 1. koji zavaren sa najkraćim vremenom $t_{8 / 5}$. Na oba spoja najveće tvrdoće imaju ZUT završnih prolaza pri čemu je tvrdoća u ZUT spoja 2. manja što se može objasniti dužim vremenima $t_{8 / 5} u$ završnim prolazima ovog spoja.

Mikrostrukturna ispitivanja pokazuju da OM ima sitnozrnu feritno-perlitnu strukturu. Uočene strukture segregacije u OM nisu prihvatljive kod čelika povišene čvrstoće, zato što one obično dovode slabljenja čelika u pravcu upravnom na površinu lima. U grubozrnom delu ZUT korenih prolaza oba spoja javljaju se feritno-beinitnoperlitna mikrostruktura. Ova mikrostruktura je, u odnosu na grubozrni deo ZUT završnih prolaza, znatno sitnija i zrna su zaobljena tj. ravoosna. U grubozrnom delu ZUT završnih prolaza oba spoja javljaju se beinitno-martenzitno-perlitna mikrostruktura. Ova mikrostruktura je, u odnosu na grubozrni deo ZUT korenih prolaza, znatno grublja. Sadržaj martenzita od oko $20 \%$ u ZUT završnih prolaza je u okviru očekivanog. 
Tokom zavarivanja moguća su odstupanja od zadate $T_{p}, T_{m p}$, ili $Q$, što onda menja vreme $t_{8 / 5}$. Količina unete toplote se može da odstupa od zadate u užim granicama zbog promene jačine struje zavarivanja (npr. usled promene dužine slobodnog kraja žice) ili zbog promene brzine zavarivanja. Sa druge strane $T_{p}$ i $T_{m p}$ se mogu da odstupaju od zadatih u širim granicama, zbog loše izvedenog predgrevanja, lošeg načina merenja temperatura, atmosferskih uticaja i ne uzimanja u obzir naknadnog zagrevanja OM toplotom električnog luka.

\section{ZAKLJUČCI}

Vreme hlađenja $t_{8 / 5}$ je parametar koji ima odlučujući uticaj na strukturu dobijenu u ZUT zavarenih spojeva čelika. Da bi ZUT imala zadovoljavajuće osobine vreme $t_{8 / 5}$ se mora naći $u$ odgovarajućim granicama, koje su specifične za svaku grupu čelika i koje zavise od hemijskog sastava i polazne strukture čelika.

Vreme $t_{8 / 5}$, ostvareno tokom zavarivanja određenog spoja, zavisi od temperature

\section{LITERATURA}

[1] Standard EN 10027-1/2015: Sistemi označavanja čelika - Deo 1: Osnovne oznake čelika

[2] Standard EN 1011 - 2/2007: Zavarivanje Preporuke za zavarivanje metalnih materijala - Deo 2: Elektrolučno zavarivanje feritnih čelika

[3] B. Bajić: Elektrolučno zavarivanje u zaštiti inertnog $i$ aktivnog gasa MIG-MAG, Gorenje Varstroj, Lendava, 1982.

[4] Ruukki: Hot rolled steel sheets, plates and coils, Welding general, Ruukki Metals Oy, Finland, 2014. predgrevanja ili međuprolazne temperature i količine unete toplote. Ukoliko je jedan od ova dva parametra ograničen, vreme $t_{8 / 5}$ se može korekcijom drugog parametra, dovesti u zahtevane granice.

Kod jednog te istog spoja, međuprolazna temperatura je obično manja od temperature predgrevanja zbog toga što se prolazi popune najčešće zavaruju sa većim unosom toplote od korenog prolaza. Samo na taj način je moguće obezbediti da vreme $t_{8 / 5}$ bude isto za koreni $i$ prolaze popune. U slučaju da su unosi toplote pri zavarivanju korenog i prolaza popune slični međuprolazna temperatura i temperatura predgrevanja mogu biti iste.

Rezultati merenja tvrdoća i makro i mikrostrukturnih ispitivanja pokazuju da, temperatura predgrevanja, međuprolazna temperatura i količina unete toplote, određeni na osnovu zadatog vremena $t_{8 / 5}$ daju zadovoljavajuće tvrdoće i mikrostrukture u ZUT sučeonog spoja čelika P 460 NL1.
[5] K. Gerić: Prsline u zavarenim spojevima, Monografija, Fakultet tehničkih nauka, Novi Sad, 2005.

[6] Katalog dodatnih materijala za zavarivanje, Elektrode Jesenice, Jesenice, 2014.

[7] H. Granjon: Metalurške osnove varjenja, prevod na slovenački P. Štular, Zveza društev za varilno tehniko Slovenije, Ljuljana, 1994.

[8] A. Radović: Zavarljivost i ispitivanje zavarljivosti, Monografija Mehanika loma zavarenih spojeva, Goša Institut, Tehnološko metalurški fakultet Beograd, Beograd, 1985. 